\title{
Is Aid for Developing Countries Destroying their Environment?
}

\author{
Kai Curry-LindahI
}

\begin{abstract}
A Vice-President of the FPS, Dr Curry-Lindahl has long experience as a scientist studying wildlife in the field, especially in Africa, as adviser on ecology and conservation to African governments, as a Council member of IUCN and as a staff member of both UNESCO and UNEP. This analysis of the ways in which technical assistance is deployed by the international organisations leads him to answer his title question with a firm 'yes'. This address was given to the FPS at the Annual General Meeting in London on July 4.
\end{abstract}

The three main environmental problems in developing countries today are the population increase, the shortage of food and the energy crisis. And these three factors are intimately connected.

In order to support vast and increasing numbers of human beings, man is forced, for short-term benefits and daily subsistence needs, to destroy productive environments at an accelerating pace, either to make room for agriculture and livestock in areas not suitable for those activities or to obtain energy for domestic use, for fertilisers or other purposes. This ongoing destruction of the renewable natural resources which support mankind is in the long-term causing an ecological disaster that undermines the future of human existence in tropical and subtropical regions of the world. It will not increase the world's food supply in the future - indeed the annual catches of marine food have decreased in recent years, and the acreage of arable land is continuously reduced.

Over the last fifty years the human population increase in the developing countries has been accompanied by a natural destruction of unparallelled proportions. Only at the expense of environmental capital has man been able to maintain a tremendous overpopulation. One must accept and draw the consequences of the cruel fact that the renewable natural resources of most developing countries are already insufficient to support their present populations. Yet, this resource capital is being consumed and destroyed at an accelerating pace, because no alternatives for daily subsistence needs are available. It is no good telling local populations, who are obliged to cut down trees in order to get domestic fuel or pasture for grazing livestock or land for cultivation, that they can no longer do so, unless an immediate alternative is provided for them.

The increasingly serious food, water and domestic fuel crisis in developing countries is a symptom of environmental destruction caused by overpopulation, but simultaneously the shortage of basic needs provokes further environmental degradation through resource capital consumption. It is a vicious circle. It is obvious that the world's food and fuel production cannot keep pace with the accelerating growth of population. It makes no difference how much food and fuel the world produces if it produces people faster.

Many governments of developing countries are aware of what is happening but, due to lack of funds, political will and social courage, they hesitate to intervene against this destruction of a precious, irreplaceable capital by 
Funds are largely spent on projects giving short-term economic returns; thus they actually contribute to the long-term environmental degradation.

\section{Technical assistance itself is in numerous cases a threat to the environment and to renewable natural resources.}

increasing populations. In many cases legislation exists to prevent such harmful land use, but it is not implemented for the reasons already mentioned. So far no multilateral or bilateral technical assistance organisations have tried to tackle the problems at their roots, or even to spell out the bitter truth to the governments they are supposed to assist.

It is obvious that this accelerating destruction in the tropics and subtropics is impossible to halt if the populations concerned are not provided with an alternative for their subsistence. This in turn requires financial assistance from developed countries and international organisations on a large scale. But today already more than 27 billion dollars go to technical assistance. So funds are available. But unfortunately these funds are largely spent on projects giving short-term economic returns; thus they actually contribute to the long-term environmental degradation and loss of renewable natural resources.

This disastrous situation emphasises the necessity of, and justification for, a radically new approach to technical assistance and development in tropical and subtropical countries. Ecologically designed emergency programmes are needed and must be an important part of any development strategy supported by technical assistance organisations. So far this has not been the case. It is indeed remarkable that in twenty years of technical assistance to developing countries the multilateral and bilateral organisations responsible for this aid have ignored ecological realities despite being continuously reminded about them by the conservation organisations. It is even more remarkable that technical assistance organisations whose representatives in developing countries have long been witnessing the ongoing destruction of renewable natural resources, have not taken any initiatives to stop it, although frequently asked to do so by nongovernmental conservation organisations. Is this passivity due to the fact that the technical assistance organisations are themselves to a large extent the cause of environmental destruction?

This question leads to another: 'Is technical assistance to developing countries environmentally destructive?'.

In my opinion the answer is yes.

In a 503-page report that I recently submitted to the Government of Sweden, at its request, I explained why I have come to this conclusion. Entitled Technical Assistance with Responsibility: Environment and Development in Developing Countries, it is based not only on published and unpublished material, but also on field work and missions on all continents and on more than a decade of experience as a staff member of both UNESCO and UNEP. The report analyses the present environmental threats in developing countries, and the conclusion it draws, I regret to say, is that the technical assistance itself is in numerous cases a threat to the environment and to renewable natural resources. During the last twenty years, through wrongly designed land use projects, development 
It is easy to increase economic growth in terms of GNP if the consumption of the capital remains invisible in the balance sheet.

\section{Too often exploitation plans are . . nothing but a plundering of resources leading to the ruin of the area concerned.}

assistance by multilateral and bilateral aid organisations has contributed considerably to the tremendous decline in the productivity of the ecosystems. The objectives of the projects have been to increase the arable acreage and food production of developing countries, as well as to ameliorate the standard of life for the people through the introduction of new working methods, knowledge and technology; but during that time in these countries the following environmental changes have occurred:

1. Every year more arable land is lost than gained;

2. Nearly 50 developing countries previously self-supporting in food have become food importers, and their number increases every year;

3 . Desertification is continuously increasing at an accelerating rate;

4. The severe detrimental consequences of erosion are increasing in both lowlands and highlands and through sedimentation in rivers, lakes and the sea;

5. Water resources are declining, the ground water table is sinking, and an increasing number of previously permanently flowing rivers are dry throughout the year; productive marshes and lakes have been drained with no long-term benefit;

6. Vegetation disappears; fertile grasslands are transformed to dry thornbush before turning to deserts; gallery forests have been cut down; lowland rain forests are eliminated; montane rain forests are destroyed, releasing rapidly operating destructive processess that frequently cause flood catastrophes in the lowlands;

7. Wild animals, important protein resources and ecological stabilisers, have vanished from many areas where they were abundant; many species are in danger of extinction;

8. Toxic chemicals are dispersed in ecosystems in larger quantities every year.

All these environmental alterations are the effects of detrimental land-use methods, and technical assistance projects have accelerated them. In the longterm sense this is not aid. It is the opposite.

Conservation organisations have tried for two decades to draw the attention of the United Nations Development Programme, FAO, the World Bank and others to the danger of neglecting ecological realities in their planning and implementation of development projects, yet these organisations continue to design projects which may give quick economic returns but which, in the longterm, are environmentally destructive. Hardly a month passes without news about this kind of project, which the non-governmental organisations try to stop or modify. But usually decisions have already been taken. Both the UNDP and the World Bank claim that they are conscious about the environment, but their actions clearly contradict this.

It is also difficult to find any environmental concern in their annual reports. Both organisations give priority to economic growth and measure their annual results in figures related to such growth, apparently without taking into account the fact that this growth has been reached at the price of irreparable losses of natural resources capital in the countries concerned. In the 1977 UNDP Report the Director of the World Bank writes, 'It is indeed a very impressive record. 
Never has so large a group of human beings - two billion people - achieved so much economic growth in so short a time'. This statement is indeed revealing. It shows that still, in 1978, neither UNDP nor the World Bank (nor the national representatives on the Boards) realised the underlying environmental consequences of their technical assistance; they have not understood the tremendous destruction of renewable natural resources in developing countries. It is easy to increase economic growth in terms of GNP if consumption of the capital remains invisible in the balance sheet. The statement in 1977 by the International Institute for Environment and Development that UNDP has a clear understanding of environmental problems is a grotesque exaggeration.

Through the projects they initiated, encouraged or financed, as well as by their philosophy, the UNDP and the World Bank constitute the two most serious obstacles to conservation organisations in their attempts to get governments in developing countries to realise the seriousness of the ongoing environmental destruction and the urgent need for taking conservation measures.

And what about UNEP? If UNEP believes that it is 'the environmental conscience of the UN system', it must take care of the planet Earth within the context of a global strategy which gives absolute precedence to the conservation, management and wise utilisation of renewable natural resources, in other words the long-term use of the environment, based on ecological principles. This implies that UNEP must oppose all unwise exploitation plans by governments, of which there are all too many, aimed at quick economic returns with no regard for long-term aspects. Too often these exploitation plans are, from the long-term and ecological points of view, nothing but a plundering of resources leading to the ruin of the area concerned. Such opposition will not make UNEP popular with governments which, for political, social or economic reasons, wish to undertake short-term projects that will provide labour and some immediate economic return for the next five years or so, but prefer to close their eyes to what will happen after that.

\section{UNEP's Failure}

So far UNEP has not intervened where, in my opinion, it should have intervened in its role as environmental conscience; examples are numerous. This and other failures have not only led to a continuous destruction of renewable natural resources, but also to a growing feeling among nations, organisations and conservationists that UNEP is gradually deviating from the expectations and the 'spirit of Stockholm' which emerged from that 1972 UN Conference on the Human Environment, and that UNEP's strategy needs to be revised. It has to be much more realistic ecologically without becoming politically and socially unrealistic. And that needs more courage, vision, persistence and conviction.

A strategy for the care of planet Earth involves a 'biosphere responsibility'. Governments must be brought to realise the necessity of maintaining the proper function of the biosphere and its resources. This is ecosystem conservation. Without a concept of, as well as clear views on, the function and management of ecosystems, it is impossible to establish a policy or propose social action that will enable tropical and subtropical environments to recover from their present impoverished state.

UNEP cannot put such a strategy into action, without the approval of its Governing Council - consisting of 58 governments. But it has not so far made any serious attempt to do so. Such an ecologically realistic long-term strategy, 
which should be its main effort to save the world, must become a crusade, with concerted efforts on a global scale, aimed at rescuing the renewable resources, biomes and ecosystems that are rapidly approaching the point of disappearance - yet another irreversible step towards the impoverishment of the world.

The effects of technical assistance projects cannot be measured in terms of economic growth without being balanced by the enormous losses of environmental capital in the form of ecosystem productivity. Hitherto development projects in developing countries have ignored the facts that such a productivity exists and that water, soil, vegetation and wildlife resources are interrelated. They have not been concerned with functions and processes of ecosystems or about conservation in general. This is tragic and has led to farreaching environmental destruction. Future governments in tropical and subtropical countries will regret that many projects promoted by the multilateral and bilateral technical assistance organisations have had disastrous environmental effects in their countries.

We have to realise that, if the present degradation of renewable natural resources in tropical and subtropical countries continues for another decade without energetic measures to stop it, there is little hope for the future of quite a number of nations and their populations.

\section{Tiger Numbers}

The representative of China at the New Delhi Tiger Symposium in February 1979, Dr Xiao Giarizhu, of the North-east China Forestry College at Harbin, brought the first news for many years of tiger numbers there. The estimate for Manchurian (Siberian) tiger Panthera tigris altaica in China was 150, the same number as the most recent estimate from the Soviet Union, which, however, was not represented at this Symposium. China has three other tiger subspecies: P.t. amoyensis in the Yangtse Valley, and P.t. corbetti and $P . t$. tigris, both in the south, but numbers for these were not given. In India the numbers of P.t. tigris are now put at 2484, compared with 1800-odd before the start of Project Tiger five years ago. The Bangladesh estimate, also of P.t. tigris, is 430, and Nepal estimates 170-220. For the Sumatran tiger P.t. sumatrensis Indonesia estimated 400-500. The Bali and Caspian tigers are feared extinct, and the Javan tiger P.t. sondaica is down to 4-5 (only tracks seen) in the Meru Betiri Reserve in eastern Java.

A correspondent in North Korea writes: North Korea has created national parks designed to protect tigers between Paiktusan, an extinct volcano near the Chinese border in the north, and the Diamond mountains near the southern demarcation line, and caves have been excavated in the parks to encourage tigers to breed. About 50 tigers live in the protected areas, and an unknown number outside - a considerable increase on the estimate of $10-20$ when the Republic was established. The mountainous areas are thinly populated and the Government appears to be anxious to preserve the tigers, which are regarded as useful in that they prey on wolves, also rats, foxes and (less popular) pigs and dogs.

\section{Management in a Drought}

'Even under very difficult conditions, nature can recover. The most extraordinary example was discovered by satellite three years ago during the famous drought south of the Sahara in the Sahel country. People observing maps saw a big area of more than a quarter million acres that was green in contrast with all the rest that was desert. That was traced to a ranch. This large acreage was fenced and divided into sections in which they have cattle. The cattle graze on one section a year, then move to the next section, and there is no browsing by any other animals because it is fenced. And if you do that even during the drought the whole thing is green.' René Dubos. 